\title{
Opinions of Physical Education Teachers on National and Cultural Values Gained Through Physical Education and Sports Activities
}

\author{
Özer YILDIZ ${ }^{1}$
}

\author{
Ahmet DEVECI ${ }^{2}$
}

Mehtap YILDIZ

\begin{abstract}
The objective of the research is to analyze the opinions of physical education teachers regarding national and cultural values gained through physical education and sports activities. In the research, the interview method has been used from qualitative research patterns. The study group consists of 19 physical education teachers (12 Male and 7 Female) selected according to the easily accessible sampling method from purposeful sampling methods, which is one of the improbable sampling strategies working at the middle and high school level in Gaziantep province in 2019-2020 Academic Year. Data have been gathered via a semi-structured interview form developed by the researchers and have been evaluated by content analysis method. According to the results of the study it has been determined that physical education teachers think that physical education and sports activities have positive effects in the development of students in terms of national and cultural values, but have various criticisms and suggestions for practice of such activities.
\end{abstract}

Keywords: Physical education and sports activities, physical education teacher, national and cultural value

\section{Beden Eğitimi ve Spor Etkinlikleri Yoluyla Kazanılan Millî ve Kültürel Değerlere İlişkin Beden Eğitimi Öğretmenlerinin Görüşleri}

\section{$\ddot{O} z$}

$\mathrm{Bu}$ araştırmanın amacı, beden eğitimi ve spor etkinlikleri yoluyla kazanılan millî ve kültürel değerlere ilişkin beden eğitimi öğretmenlerinin görüşlerinin incelenmesidir. Araştırmada nitel araştırma desenlerinden görüşme yöntemi kullanılmıştır. Araştırma grubunu 2019-2020 Eğitim-Öğretim Yılında Gaziantep ilinde ortaokul ve lise kademesinde görev yapan olasılıksız örnekleme stratejilerinden biri olan amaçlı örnekleme yöntemlerinden kolay ulaşılabilir örnekleme yöntemine göre seçilen 19 beden eğitimi öğretmeni (12 Erkek, 7 Kadın) oluşturmaktadır. Veriler araştırmacılar tarafından geliştirilen yarı yapılandırılmış görüşme formu yoluyla toplanmış ve içerik analizi yöntemi ile değerlendirilmiştir. Araştırmanın sonuçlarına göre beden eğitimi öğretmenlerinin milli ve kültürel değerler açısından, beden eğitimi ve spor etkinliklerinin öğrencilerin gelişim alanlarında olumlu etkiler oluşturduğunu düşündükleri ancak bu tür etkinliklerin uygulanmasına yönelik çeşitli eleştirilerinin ve önerilerinin olduğu tespit edilmiştir.

Anahtar Kelimeler: Beden eğitimi ve spor etkinlikleri, beden eğitimi öğretmeni, millî ve kültürel değer

Necmettin Erbakan University, Ahmet Kelesoglu Educational Faculty, Konya-Turkey, oyildiz74@gmail.com https://orcid.org/0000-0002-2470-5457

Hatay Mustafa Kemal University, Physical Education and Sports School, Hatay-Turkey e-mail ahmetdeveci08@gmail.com https://orcid.org/0000-0003-1814-3539

3 Necmettin Erbakan University, Ahmet Kelesoglu Educational Faculty, Konya-Turkey, yildizmehtap77@gmail.com https://orcid.org/0000-0001-8553-7154 


\section{INTRODUCTION}

Education, in general terms, has been defined as the process of raising and directing individuals according to certain purposes on the basis of creating desired behaviors on individuals. The personality of the individual involved in this process differs. However, the knowledge, skills, attitudes and values gained through education lie on the basis of this differentiation (Quoted Öçalan \& Erdoğdu, 2009).

It is seen that the concept of education has been one of the most popular concepts in every field from the past to the present, and educational institutions are the leading institutions in this field. In fact, the reason why educational institutions are so important is that they are institutions that undertake the locomotive role in the transfer of values that protect the indivisible integrity of a community. Although individuals are left alone with value education by their parents since they opened their eyes to life, it can be said that it is possible to raise more conscious individuals about the concept of value due to the planned and programmed value education given by educational institutions. Schwartz (1994) the concept of value, it is defined as the beliefs that the individual aims and strives for, and that guides the choice of behavior preferences or the evaluation of these behaviors and preferences.

When the education curricula of the countries are investigated, it is observed that the practices related to values education are included in the curricula of educational institutions as a state policy. Basically, the universal values that students want to gain in these curricula are; according to Topal (2019) responsibility, benevolence, morality, leadership, justice, righteousness, discipline etc. are the values that direct the individual to the ideal human line (Topal, 2019). Every person has numerous values with different degrees of importance (Bardi \& Schwartz, 2003). People who grow up in society and the education they receive impress their value choices. These values affect human life deeply and guide the evaluation of behavior and events (Schwartz \& Bilsky, 1987). Therefore, it can be said that social values are transferred to future generations through education, and education as institution and educators play a crucial role in value transfer (Altun, 2003).

Bailey (2006), Bailey and et al. (2009) stated that one of the initial duties of educational institutions in most countries is to promote social and moral development of young people so that they can become productive citizens and make positive contributions to society (Bailey, 2006; Bailey and et al., 2009 ). It can be said that one of the courses that provide these value gains is physical education and sports (PES) lessons. In fact, all classes in schools, inclusive PES, are expected to place this task at the centre of education period (Hardman \& Marshall, 2005; Pühse \& Gerber, 2005). Indeed, there is evidence in the literature that PES activities, when properly structured, can promote positive developmental outcomes for young people and promote moral character development (FraserThomas, Côté \& Deakin, 2005; Gould \& Carson, 2008; Bailey, 2006; Etnier et al., 1997; Landers \& Petruzzelo, 1994 ). For example, Gould and Carson (2008) defended that sports can provide a suitable background for progress of various perfections, inclusive values that can profit young people's personel devolopment.

In general, it is clearly seen in the literature that PES lessons, which are included in formal education curricula of most countries, also lead a healthy lifestyle. PES lessons have a multifunctional structure by nature. In this context, PES lesson enables the formation of ethical and spiritual qualifications of person, supporting psychomotor development, organization of beneficial social and professional activities, enabling the prevention of diseases and rehabilitating various ailments (Prysiazhniuk et al., 2018). However, PES lessons not only provide physical development, but also contribute to the emotional and mental progress of students. For this reason, it is a fact that many values can be gained to students in PES lessons (Yıldız \& Güven, 2013). However, PES lessons, it not only helps students stay fit, develop motor skills and muscle strength, but also contributes to the development of many values such as sportsmanship, teamwork, honesty, self-esteem, striving for the best individual performance, group attendance. Therefore, it can be said that PES lessons have a crucial place in promoting and developing both individual and social values in students. One of the phenomena, which is an important platform in the acquisition and transfer of these values, is the national holidays celebrated in a cheerful way.

National holidays are one of the basis notions that reveal the common pleasures and values of society (Elias, 2018). Eventhough societies have experienced negative events in different ways from the past to the present, they have some unique values that they respect. These values, which exist in societies, allow distances and the same excitement to be felt in all geographies of countries. In this respect, these values are the basic building blocks that provide the consciousness of being a nation. Values have emerged from the common experiences of a culture, spread, preserved and transferred from generation to generation. Even 
when evaluating some international situations, events are viewed in terms of values. In fact, in various situations, values can be so decisive that even in this sense, international relations can come to a standstill. When we look at the national values of the Turkish society, the flag, patriotism, national anthem, independence, religious beliefs, traditions and customs, recent struggles, state and national elders, historical personalities, etc. can be counted (Çetin, 2015).

While national holidays enable nations to come together around the lofty goals they want to achieve, create a sense of belonging, develop common beliefs and values, they also function as a tool in transferring values to future generations (Uzun, 2010; Şavkili \& Ertem, 2019). In national holidays, there are activities with wide participation every year in order to ensure that first of all, the young generations, and the whole society in general, can boast about their past and raise new generations that will create the national state forever (Akbayrak, 1987). It can be said that one of the most important of these activities is PES activities. Through PES activities, it is possible to raise individuals who have national and cultural values, are hardworking, productive, creative, helpful, and assimilate the behaviors required by democratic life (Arac1, 2000). Therefore, it can be thought that national holidays will be an important tool in providing value gains in this regard.

As a result, culture and its inseparable part PES activities should be regarded as an activity aimed at creating efficient conditions to support physical and spiritual progress. Developing students on the basis of universal values that will contribute to national, ethical, cultural and aesthetic values and providing professional improvement with the target of more self-realization is only possible with PES lessons and activities (Bulger, 2015).

Students in PES activities, it is considered significant by the society to exhibit positive or negative behaviors in accordance with the individual or cultural structure in the national, social, moral and conscientious sense, and what the value perceptions and perspectives of the physical education teachers and students regarding these activities. In this regard, in order to understand the value indicators of the students participating in PES activities, and to examine the thoughts of physical education teachers about the values gained in various PES activities, it is necessary to examine the opinions of physical education teachers. Determining the value indicators of students who experience PES activities and the values that are gained to students and society through these activities, it is important from the point of adapting to social changes and transferring values to future generations. As a result, the aim of the research is "Examination of the Opinions of Physical Education Teachers on National and Cultural Values Gained through Physical Education and Sports Activities".

\section{METHOD}

\section{Research Model}

Qualitative research method has been used in this study. Qualitative research method tries to understand the reasons behind the behavior of individuals and the social reality, it is a nonquantitative research type in which qualitative data collection techniques such as interview and document analysis are used (Gürbüz \& Şahin, 2018). However, in this method, the present results cannot be generalized, but provide a perspective on the subject (Yıldırım \& Şimşek, 2018).

In the research, phenomenology research pattern, which is one of the qualitative research patterns, has been used to determine the framework of the research. Phenomenology research focuses on how individuals perceive the phenomena they live and experience, what meanings they attribute to them, what they feel, how they describe them, and what meanings they share with other people (Patton, 2002). Person experiences form the basis of the phenomenological approach. In other words, in this approach, the researcher deals with the subjective experiences of the participant and examines the perceptions of the individual and the meanings they attribute to the events. Phenomenology is a descriptive study. In this sense, it should not be forgotten that it is significant not to generalize but to describe the phenomenon (Akturan \& Esen, 2008).

In research, incorporating the views of physical education teachers for specify the values gained by the students in PES activities and the thoughts of physical education teachers about these activities, laid the groundwork for the use of the interview method. This method is a data collection method based on taking, recording and qualitatively analyzing the opinions of certain people or persons on the subject for the purpose of the research (Karasar, 2008; Kuş, 2003; Punch, 2005; Yıldırım \& Şimşek, 2018). Data have been acquired via semi-structured interview method. This method has the flexibility to be adapted to different study cases (Punch, 2005). In this type of interviews, there are no standard, pre-prepared questions, and there are no restrictions on the answers (Yıldırım \& Şimşek, 2018). In other words, in a semi-structured interview, the researcher is sometimes allowed to go beyond the determined questions and touch on 
special issues while asking questions to the participants (Berg \& Lune, 2019).

\section{Research Group}

In study, purposive sampling method (Merriam, 2018), which is one of the non-probability sampling strategies used in qualitative research, and easily accessible sampling method, which is one of the purposeful sampling methods, have been used (Yıldırım \& Şimşek, 2018).

Qualitative studies do not have to provide an sufficient sample size based on precise and statistical calculations (Ritchie, Lewis \& Elam, 2003). It is important that the qualitative sample size is adequate to ensure that all relevant information is discovered (Morse, 2010). Satisfaction principle guided the sample size at this stage. Satisfaction is the situation in which new perspectives, insights, experiences or data are not revealed when enough participants are interviewed (Morse, 2010; Shank, 2006; Teddlie \& Tashakkori, 2009). Vagle (2014) states that in phenomenological studies, there is no defined number for participant size (Vagle, 2014). In some studies, it was stated that the number of participants should be between 5 and 25 , while in some studies it was stated that there should be at least 10 people. However, the general consensus is that the number of participants is small. The data collection phase should be terminated when the opinions obtained from the participants in the researches start to be repeated. Therefore, at this stage, the researcher should perform the termination task when data adequacy occurs (Yıldırım \& Şimşek, 2018; Creswell, 2018). Since data saturation was reached in this study, the research group ended with 19 physical education teachers (12 Male, 7 Female).

The study group consists of 19 physical education teachers (12 Male and 7 Female) selected according to the easily accessible sampling method from purposeful sampling methods, which is one of the improbable sampling strategies working at the middle and high school level in Gaziantep province in 2019-2020 Academic Year. Nickname codes were given to the participants (as Ö1, Ö2, Ö3,..) who attended in the interview.

Table 1. Distribution of the Data of the Research Group on the Participant Codes, Gender, Age, Professional Seniority, Education Status and Interview Dates

\begin{tabular}{|c|c|c|c|c|c|}
\hline Participant Code & Gender & Age & Professional Seniority & Education Status & Interview Date \\
\hline Ö1 & Male & 26 & 5 & Bachelor's Degree & 30.09 .2019 \\
\hline Ö2 & Male & 29 & 4 & Master's Degree & 01.10 .2019 \\
\hline Ö3 & Male & 31 & 9 & Bachelor's Degree & 02.10 .2019 \\
\hline Ö4 & Male & 42 & 12 & Bachelor's Degree & 07.10 .2019 \\
\hline Ö5 & Female & 37 & 16 & Bachelor's Degree & 10.10 .2019 \\
\hline Ö6 & Female & 34 & 11 & Bachelor's Degree & 11.10 .2019 \\
\hline Ö7 & Female & 27 & 5 & Bachelor's Degree & 17.10 .2019 \\
\hline Ö8 & Female & 29 & 4 & Bachelor's Degree & 22.10 .2019 \\
\hline Ö9 & Female & 29 & 6 & Bachelor's Degree & 24.10 .2019 \\
\hline Ö10 & Female & 33 & 5 & Bachelor's Degree & 06.11 .2019 \\
\hline Ö11 & Female & 27 & 6 & Bachelor's Degree & 12.11 .2019 \\
\hline Ö12 & Male & 39 & 16 & Bachelor's Degree & 15.11 .2019 \\
\hline Ö13 & Male & 38 & 13 & Bachelor's Degree & 16.11.2019 \\
\hline Ö14 & Male & 33 & 7 & Bachelor's Degree & 18.11.2019 \\
\hline Ö15 & Male & 28 & 4 & Bachelor's Degree & 20.11 .2019 \\
\hline Ö16 & Male & 37 & 14 & Bachelor's Degree & 21.11.2019 \\
\hline Ö17 & Male & 30 & 3 & Master's Degree & 22.11 .2019 \\
\hline Ö18 & Male & 24 & 1 & Bachelor's Level & 25.11 .2019 \\
\hline Ö19 & Male & 29 & 8 & Bachelor's Level & 26.11 .2019 \\
\hline
\end{tabular}

As can be observed in Table 1, in the way of gender; a total of 19 physical education teachers, 7 Female and 12 Male, participated in the research, and the participants were between 24 and 42 years old, it is seen that the professional seniority of the participants varies between 1 and 16 years, and finally, in terms of the educational status of the participants, 2 of the participants have a master's degree and 17 participants have a bachelor's degree.

\section{Data Collection Tools}

Interview method is one of the most basic data collection techniques in phenomenological studies. However, in phenomenological studies, written materials, observation, social media, visual tools, etc. It is also known that it is possible to benefit from various data collection techniques such as (Saban \& Ersoy, 2017). In research, data have been collected through a semi-structured interview form developed by researchers. In the process of 
structuring the interview form, a literature review was conducted on value orientations in general, and value orientations in PES in particular, related researches were examined, and after the questions determined by two subject experts were approved, questions were formed. The pilot application of the form was carried out with four physical education teachers, and the interview form, which was finalized as a result of the re-evaluation of the questions by subject experts and researchers, composed of two open-ended questions. In personal information form, information concerning the gender, age, professional seniority and educational status of the physical education teachers are included. In interview form, there are three openended questions, prepared to determine the thoughts of physical education teachers about national and cultural values gained through PES activities.

The aim of asking an open-ended and comprehensive question in the research is to try to provide the richness of the data obtained from the sample in a flexible and open-ended manner (Yıldırım \& Şimşek, 2018). Semi-structured interview form permitted flexibility in the way and order in which questions have been asked, while ensuring that all participants have been asked the similar general questions (Shank, 2006). In this way, open-ended interview questions provided the participants with a way of expressing their understanding, perceptions and experiences (Roulston, 2010).

\section{Data Collection}

The research data were collected between September and November 2019, by obtaining permission and appointment from physical education teachers, during lunch breaks during school hours, during free lessons, and through individual interviews in out-of-school cafe environments. Before each interview started, the participants had been informed regarding the aim and procedures of the research.

During the interview, a comfortable interview environment was created so that the participants felt comfortable about sharing their life experiences with the researcher (Roulston, 2010). Face-to-face interview sessions started in a conversational style. This approach has been used to help build relationships and relax the participant in the interview environment (Teddlie \& Tashakkori, 2009).

Each interview with the participants lasted approximately 20 to 30 minutes. The obtained data were recorded with a mobile phone with voice recording feature, with the consent of the participants. Finally, the opinions of the participants were converted into a total of 54 pages of raw data in word format using a computer.

\section{Analysis of Data}

In order to draw a conclusion from the data obtained as a result of the interviews made in the research, the interview forms were transferred to the electronic environment and turned into a regular written document. The participants (12 Male, 7 Female) included in the interview were given different nicknames in order to keep their personal information confidential. The answers given by the participants to the open-ended questions in the interview form were read line by line and analyzed systematically with the content analysis method.

Content analysis is careful, detailed and systematic examination and interpretation of a particular material in order to detect patterns, themes, prejudices and meanings (Berg \& Lune, 2019). The main purpose of content analysis is to reach concepts and relationships that can explain the collected data. Through this analysis, it is aimed to identify the data and find out the facts that may be hidden in the data (Yıldırım \& Şimşek, 2018). In this analysis, attention is paid to the processes of what data will be included in the analysis, what will be analyzed, how to use the analysis steps and coding tables effectively (Berg \& Lune, 2019).

Content analysis consists of four stages: coding the data, finding the themes, organizing the data according to the codes and themes, defining and interpreting the findings (Yıldırım \& Şimşek, 2018).

In qualitative data analysis, coding is one of the initial and most important tasks to discover the contents of raw data and analyze this data (Punch, 2005). While conducting the interviews during the implementation phase of the research, the researchers ask questions to the participants in line with the purposes of the research. In the continuation of this process, the participants openly express their thoughts by responding to the researchers. Finally, researchers have to document the answers given by the participants to the questions they ask, and analyze the basic thinking tendencies of the participants on the subject of the research. Therefore, this solution process performed in qualitative data analysis is called coding (Glesne, 2013). The main goal in content analysis is to collect similar data based on these codings within the framework of particular concepts and themes and to interpret these data by putting them in an understandable order (Yıldırım \& Şimşek, 2018).

The reliability of the content analysis method depends on the coding process. The most important stage of this process is the identification and clear 
definition of the themes. The interpretations of the themes do not change from researcher to researcher ensures reliability, which is a condition of objectivity. The interview data set should be given to different researchers at a time and the correlation between the results obtained should be calculated. In addition, this method is both effective and easy to apply against the distorting effect of memory (Miles \& Huberman, 1994). For this reason, the data set, which was turned into a written document, was given to two experts and the correlation between the results obtained from each of them was calculated.

Reliability calculation of the data was calculated by using the Consensus theme / Consensus + Disagreement theme X 100 formula. According to the formula result, the consistency between the themes/codes should be $70 \%$ or more (Miles \& Huberman, 1994).

As a result of the application of the formula, 30 of the 32 codes suggested by the experts were approved, and the compatibility between the themes/codes was determined as $30 / 32 \times 100=93.75$. The 2 codes on which no consensus could be reached were combined with other appropriate codes.

In addition, frequency analysis, which is one of the content analysis types, had been used in this research. Unit or items through frequency analysis; are presented in numerical, percentage and proportional manner. This situation provides a perspective to the researcher and the reader by revealing the frequency of appearance (repetition) of the views expressed by the participants.
Therefore, frequency analysis allows to understand the intensity and importance of a particular element. From this point of view, after frequency analysis is done, a classification based on frequency is made by placing the items and units in order of importance (Bilgin, 2014).

\section{Validity and Reliability of the Research}

It is possible to use alternative concepts suitable for the nature of qualitative research instead of the concepts of validity and reliability in qualitative research. In this framework, "credibility" can be used inside of "internal validity", "transferability" inside of "external validity", "consistency" inside of "internal reliability" and "confirmability" inside of "external reliability" (Yıldırım \& Şimşek, 2013; Creswell, 2018; Merriam, 2018). Validity and reliability in a study; they are important concepts in terms of revealing the scientificity, credibility, measurability, generalizability and reproducibility of the study (K1lınç, 2018). In this context, the strategies of credibility, long-term interaction, depth-oriented data collection, expert review, participant confirmation, confirmability, transferability, and consistency have been used to ensure the validity and reliability of this research (Yıldırım \& Şimşek, 2018).

\section{Results}

In this section, the data concerning to the study group have been examined in terms of different themes and codes, and the themes and codes were explained with percentage and frequency distributions, and direct quotations from the participants related to the themes have been included. 
Y1ldız Ö., Deveci A. \& Yıldız Ö. (2021). Opinions of Physical Education Teachers on National and Cultural Values Gained Through Physical Education and Sports Activities. International Journal of Recreation and Sport Science, 5(1); 90-104.

Table 2. Findings Concerning the Opinions of Physical Education Teachers on What Kinds of Learning Outcomes are Achieved in School Physical Education and Sports Activities during National Holidays Ceremonies

\begin{tabular}{|c|c|c|c|c|c|}
\hline Theme & Code & Participants & $\mathbf{F}$ & $\%$ & Example Expressions \\
\hline \multirow{11}{*}{$\begin{array}{l}\text { Learning } \\
\text { Outcome } \\
\text { (National- } \\
\text { Cultural- } \\
\text { Personal-Social } \\
\text { Society) }\end{array}$} & Unity and Togetherness & Ö5,Ö8,Ö9,Ö10,Ö11,Ö16,Ö18 & 7 & 19.44 & $\begin{array}{l}\text { I think that there are activities that inculcate working in cooperation, helping each } \\
\text { other, and that the group is important, not the individual (Ö18)... }\end{array}$ \\
\hline & National Consciousness & Ö5,Ö6,Ö10,Ö12,Ö15,Ö17,Ö13 & 7 & 19.44 & $\begin{array}{l}\ldots \text { These are the times when national consciousness awareness is at its peak. } \\
\text { These days, our students realize what our ancestors have overcome under limited } \\
\text { conditions and have the belief that they can do their best for their country and } \\
\text { nation (Ö6)... }\end{array}$ \\
\hline & National Feeling & Ö1,Ö3,Ö4,Ö5,Ö8,Ö14 & 6 & 16.66 & $\begin{array}{l}\text {...Such holidays remind us how necessary and important the homeland is and } \\
\text { make us understand that time, albeit a little. How Does? Children of their age } \\
\text { fought fiercely at the front when they were only } 15 \text { or } 16 \text { years old. To these } \\
\text { young people; For the national unity of the country, for the flag, for the honor, } \\
\text { telling or making people watch that the people of that period were martyred at a } \\
\text { young age not only instills national feeling, but also reminds them to whom they } \\
\text { owe their comfortable and beautiful life. National holidays are very important in } \\
\text { this respect. (Ö14)... }\end{array}$ \\
\hline & $\begin{array}{l}\text { Transferring Cultural } \\
\text { Values to Future } \\
\text { Generations and Keeping } \\
\text { them alive }\end{array}$ & Ö7,Ö11,Ö12 & 3 & 8.33 & $\begin{array}{l}\text { It is a fact that there are very important practices in order to learn the customs, } \\
\text { traditions, customs and culture of the students and to continue them in our future } \\
\text { generations (Ö7). }\end{array}$ \\
\hline & $\begin{array}{l}\text { Knowing the Past is } \\
\text { Guiding for the Future }\end{array}$ & Ö10,Ö18,Ö19 & 3 & 8.33 & $\begin{array}{l}\text {...National holidays are the most valuable activities that enable the noble Turkish } \\
\text { nation to see its future by looking at its past (Ö10)... }\end{array}$ \\
\hline & Social Development & Ö5,Ö10,Ö18 & 3 & 8.33 & $\begin{array}{l}\text {...National holidays enable getting to know other students, working together, } \\
\text { acting together and socializing in school activities and competitions (Ö10)... }\end{array}$ \\
\hline & Self-confidence & Ö8,Ö9,Ö15 & 3 & 8.33 & $\begin{array}{l}\text {...The performances these days enable students to get rid of their feelings such as } \\
\text { shyness and improve their sense of self-confidence (Ö15)... }\end{array}$ \\
\hline & Respect & Ö15,Ö14 & 2 & 5.55 & $\begin{array}{l}\text { These ceremonies not only develop the national consciousness of the students, but } \\
\text { also develop values such as respect that cannot be learned in other lessons } \\
\text { (Ö15)... }\end{array}$ \\
\hline & $\begin{array}{l}\text { Taking Duty and } \\
\text { Responsibility }\end{array}$ & Ö12 & 1 & 2.77 & $\begin{array}{l}\ldots . \text { In-school and out-of-school activities held on national and official holidays } \\
\text { improve the sense of duty and responsibility in ceremonies as gains (Ö12)... }\end{array}$ \\
\hline & $\begin{array}{l}\text { Representing the Group in } \\
\text { the Best Way }\end{array}$ & Ö12 & 1 & 2.77 & $\begin{array}{l}\text {...In the ceremonies organized to celebrate national and official holidays with } \\
\text { enthusiasm, our students understand the importance of representing their group in } \\
\text { the best possible way (Ö12)... }\end{array}$ \\
\hline & & Total & 36 & 100 & \\
\hline \multirow{6}{*}{$\begin{array}{l}\text { Critical } \\
\text { Perspective }\end{array}$} & $\begin{array}{l}\text { Doesn't Matter and Have } \\
\text { No Meaning } \\
\end{array}$ & Ö1,Ö2,Ö3,Ö4,Ö12 & 5 & 41.66 & $\begin{array}{l}\text { Although I think that it has developed a bit of national feelings, I do not think that } \\
\text { it has much meaning and importance for students and parents today (Ö1)... }\end{array}$ \\
\hline & $\begin{array}{l}\text { Having Ceremonies Held } \\
\text { Only for the Purpose of } \\
\text { Formality }\end{array}$ & Ö2,Ö13,Ö19 & 3 & 29.99 & $\begin{array}{l}\text { I don't think it does any good for the kids. I think it's just official ceremonies for } \\
\text { speeches (Ö2)... }\end{array}$ \\
\hline & $\begin{array}{c}\text { Repetitive Practices Not } \\
\text { Based on Students Keep } \\
\text { Students Away from } \\
\text { Activities } \\
\end{array}$ & Ö4,12 & 2 & 16.66 & $\begin{array}{l}\text {...Due to the same type of celebrations that follow one another and do not change } \\
\text { for years, students want to avoid such activities. Activities that do not take the } \\
\text { student as a basis, lack the sense of fun, and lose their excitement make the } \\
\text { students bored (Ö4)... }\end{array}$ \\
\hline & Failure in Togetherness & Ö12 & 1 & 8.33 & $\begin{array}{l}\text { Unfortunately, I think that unity could not be achieved in the celebration of } \\
\text { national holidays (Ö12)... }\end{array}$ \\
\hline & $\begin{array}{l}\text { Failure to Balanced Task } \\
\text { Distribution } \\
\end{array}$ & Ö12 & 1 & 8.33 & $\begin{array}{l}\text {...I think that there is no effective distribution of tasks other than certain students } \\
\text { (Ö12)... }\end{array}$ \\
\hline & & Total & 12 & 100 & \\
\hline \multirow{5}{*}{ Suggestion } & $\begin{array}{l}\text { Organizing Ceremonies } \\
\text { on Voluntary Basis in the } \\
\text { Form of Play and } \\
\text { Entertainment }\end{array}$ & Ö8,Ö12 & 2 & 33.3 & $\begin{array}{l}\text {...In this regard, by making the children adopt national feelings, at the same time, } \\
\text { it will be more positive if the works to be carried out during the holidays are based } \\
\text { on volunteerism and celebrated in the form of games and entertainment without } \\
\text { torturing the children (Ö8)... }\end{array}$ \\
\hline & $\begin{array}{l}\text { Making Students Do } \\
\text { Studies According to } \\
\text { Their Talents }\end{array}$ & Ö13,Ö18 & 2 & 33.3 & $\begin{array}{l}\begin{array}{l}\text {...Activities based on the student's individual performance and personal abilities } \\
\text { bring great benefits (Ö13)... }\end{array} \\
\end{array}$ \\
\hline & $\begin{array}{l}\text { Briefly Conducting } \\
\text { Ceremonies Every Year } \\
\text { Without Extending } \\
\end{array}$ & Ö3 & 1 & 16.66 & $\begin{array}{l}\text {...I am of the opinion that the celebrations should be held briefly without being } \\
\text { extended and that they should continue routinely every year (Ö3). }\end{array}$ \\
\hline & $\begin{array}{l}\text { Gaining the Love of the } \\
\text { Country with Effective } \\
\text { Activities in Ceremonies }\end{array}$ & Ö4 & 1 & 16.66 & $\begin{array}{l}\text {...A love of country can be gained to students through good and effective studies. } \\
\text { There are schools that conduct exemplary studies on this subject (Ö4)... }\end{array}$ \\
\hline & & Total & 6 & 100 & \\
\hline
\end{tabular}

When Table 2 is investigated, it has been designated that the physical education teachers' views on what kind of gains are achieved in the PES activities held at the school during the ceremonies held on national holidays are grouped under the themes of "Learning Outcome (f36)", "Critical Perspective (f12)" and "Suggestion (f6)". "Learning Outcome" theme respectively; "Unity and Togetherness (f7)", "National Consciousness (f7)", "National Feeling (f6)", “Transferring Cultural Values to Future Generations and Keeping them Alive, "Knowing the Past is Guiding for the Future (f3)", "Social Development ( f3)", "Selfconfidence (f3)", "Respect (f2)", "Taking Duty and Responsibility (f1)" and "Representing the Group in the Best Way (f1)", "Critical Perspective" theme respectively; "Doesn't Matter and Have No

Meaning (f5)", "Having Ceremonies Held Only for the Purpose of Formality (f3), "Repetitive Practices Not Based on Students Keep Students Away from Activities (f2)", "Failure in Togetherness (f1)", and "Failure to Balanced Task Distribution (f1)" and finally "Suggestion" theme respectively; "Organizing Ceremonies on Voluntary Basis in the Form of Play and Entertainment (f2)", "Making Students Do Studies According to Their Talents (f2)", " Briefly Conducting Ceremonies Every Year Without Extending (f1)" and "Gaining the Love of the Country with Effective Activities in 
Y1ldız Ö., Deveci A. \& Yıldız Ö. (2021). Opinions of Physical Education Teachers on National and Cultural Values Gained Through Physical Education and Sports Activities. International Journal of Recreation and Sport Science, 5(1); 90-104.

Ceremonies (f1)" appears to occur. In addition, in Table 2, sample statements directly quoted from the participants are included to support the relevant themes and codes.

Table 3. Findings Concerning the Opinions of Physical Education Teachers on Teaching Activities Reflecting Our Cultural Values such as Folk Dances and Traditional Games in Physical Education Lessons

\begin{tabular}{|c|c|c|c|c|c|}
\hline Theme & Code & Participants & $\mathbf{F}$ & $\%$ & Example Expressions \\
\hline \multirow{7}{*}{$\begin{array}{l}\text { Positive } \\
\text { Impact }\end{array}$} & $\begin{array}{l}\text { Importance of Culture } \\
\text { in terms of Surviving } \\
\text { and Transferring it to } \\
\text { Future Generations }\end{array}$ & Ö1,Ö2,Ö3,Ö5,Ö6,Ö7,Ö8,Ö10,Ö11,Ö12,Ö14,Ö15,Ö19 & 13 & 52 & $\begin{array}{l}\text {...As teachers, our duty is; is to raise a generation whose young } \\
\text { generations will take care of our traditions, customs and spiritual } \\
\text { cultures. It is the most important element of this in folk dances and } \\
\text { traditional games. A nation that does not know its past cannot see its } \\
\text { future (Ö10). }\end{array}$ \\
\hline & $\begin{array}{l}\text { A sense of belonging } \\
\text { to a group provides } \\
\text { team spirit and self- } \\
\text { confidence }\end{array}$ & Ö8,Ö14,Ö15,Ö18 & 4 & 16 & $\begin{array}{l}\text {...Belonging to a group; provides collaboration and self-confidence } \\
\text { gain. Games that reflect our cultural values, such as these games, } \\
\text { should definitely be taught in physical education lessons. However, } \\
\text { the next stage of this, the demonstration part, should also be } \\
\text { included. Because students want to be rewarded for their efforts, } \\
\text { they want to be appreciated and reinforced by exhibiting what they } \\
\text { have learned in front of a group. These situations develop self- } \\
\text { confidence in students and instill a spirit of cooperation in students } \\
\text { (Ö8)... }\end{array}$ \\
\hline & $\begin{array}{l}\text { Supporting Social } \\
\text { Development }\end{array}$ & Ö9,Ö15,Ö16,Ö19 & 4 & 16 & $\begin{array}{l}\text { As a school, we also participate in such events. Relationships } \\
\text { between students develop through such activities. Therefore, our } \\
\text { values such as folk dances are great riches in terms development of } \\
\text { society and social development and also in terms of culture (Ö9). }\end{array}$ \\
\hline & $\begin{array}{l}\text { Being a Direct Factor } \\
\text { in Gaining National } \\
\text { and Spiritual Values }\end{array}$ & Ö16,Ö17 & 2 & 8 & $\begin{array}{l}\text { The sports branches also carry the motifs of the geography and } \\
\text { country in which they live at the same time. Folk dances or } \\
\text { traditional games that contain our traditional and cultural values are } \\
\text { directly effective in the formation of national and spiritual values. } \\
\text { For this reason, I am a teacher who believes that such games should } \\
\text { be included in the physical education curriculum more than } \\
\text { necessary. Because national and spiritual values help to strengthen } \\
\text { the sense of unity and solidarity in the person (Ö17). }\end{array}$ \\
\hline & $\begin{array}{c}\text { Removal from } \\
\text { Harmful Habits }\end{array}$ & Ö16 & 1 & 4 & $\begin{array}{l}\text {...It enables students to move away from potentially harmful habits } \\
\qquad(\mathrm{O} 16) \ldots\end{array}$ \\
\hline & $\begin{array}{l}\text { Being Important for } \\
\text { Country Promotion }\end{array}$ & Ö7 & 1 & 4 & $\begin{array}{l}\text {...Good event to introduce our culture to students from different } \\
\text { countries }(\ddot{O} 7) \ldots\end{array}$ \\
\hline & & Total & 25 & 100 & \\
\hline \multirow{4}{*}{ Suggestion } & $\begin{array}{l}\text { Religiously Only Men } \\
\text { Participation in } \\
\text { Cultural Activities }\end{array}$ & Ö3 & 1 & 33.33 & $\begin{array}{l}\text { As a physical education teacher, I don't want to be thought of as } \\
\text { sexist. However, I am in favor of teaching folk dances only to male } \\
\text { students. I am giving this answer by looking at the subject from a } \\
\text { religious point of view, I do not want to go into details (Ö3)... }\end{array}$ \\
\hline & $\begin{array}{c}\text { Training of } \\
\text { Professional Educators } \\
\text { on Folk Dances }\end{array}$ & Ö13 & 1 & 33.33 & $\begin{array}{l}\text { It should be in the annual plans. In particular, I am in favor of } \\
\text { making traditional games compulsory in primary education plans. } \\
\text { For example, I am in favor of a professional folk dances team } \\
\text { teacher giving lessons to the students for a month in return for } \\
\text { additional lessons. This both develops our spiritual values. It also } \\
\text { makes physical education lessons more fun (Ö13). }\end{array}$ \\
\hline & $\begin{array}{c}\text { Carrying out Studies } \\
\text { to Protect Cultural } \\
\text { Values }\end{array}$ & Ö4 & 1 & 33.33 & $\begin{array}{l}\text {...There is an urgent need to start country-level studies on this issue. } \\
\text { First of all, our physical education teachers, who have deficiencies } \\
\text { related to the subject, should be trained with an in-service training. } \\
\text { Then, folk dances and traditional games should be included in the } \\
\text { curriculum and students should be provided to experience and love } \\
\text { these activities. These values, which cover an important part of our } \\
\text { culture and include sports, activities, culture, customs and traditions, } \\
\text { will not be forgotten in this way (Ö4). }\end{array}$ \\
\hline & & Total & 3 & 100 & \\
\hline \multirow{3}{*}{$\begin{array}{l}\text { Critical } \\
\text { Perspective }\end{array}$} & $\begin{array}{l}\text { Inadequacy of Current } \\
\text { Teachers in Teaching } \\
\text { Cultural Values }\end{array}$ & Ö1 & 1 & 50 & $\begin{array}{l}\text { These are certainly important for the survival of our cultural values. } \\
\text { However, I do not think that physical education teachers are very } \\
\text { sufficient in this regard (Ö1). }\end{array}$ \\
\hline & $\begin{array}{l}\text { Disappearance of } \\
\text { Cultural Values Rather } \\
\text { Than Being Taught }\end{array}$ & Ö4 & 1 & 50 & $\begin{array}{l}\text { Today, unfortunately, one of our greatest values, which is being lost, } \\
\text { is our folk dances and traditional games. These values, which have } \\
\text { been handed down from generation to generation, are almost } \\
\text { extinct. One of the biggest reasons for this to happen is that we can't } \\
\text { make our past a culture (Ö4)... }\end{array}$ \\
\hline & & Total & 2 & 100 & \\
\hline
\end{tabular}

F: Frequency $\%:$ Percent

When Table 3 is investigated, it has been detected that the opinions of physical education teachers on teaching activities that reflect our cultural values such as folk dances and traditional games in PES lessons are gathered under the themes of "Positive Impact (f25)", "Suggestion (f3)" and "Critical Perspective (f2)". "Positive Impact" theme respectively; "Importance of Culture in terms of Surviving and Transferring it to Future Generations (f13)", "A sense of belonging to a group provides team spirit and self-confidence (f4)", "Supporting Social Development (f4)", "Being a Direct Factor in Gaining National and Spiritual Values (f2)", "Removal from Harmful Habits (f1)" and "Being Important for Country Promotion (f1)",

"Suggestion" theme respectively; "Religiously Only Men Participation in Cultural Activities (f1)", "Training of Professional Educators on Folk Dances (f1) and "Carrying out Studies to Protect Cultural Values (f1)" and finally "Critical Perspective" theme respectively; "Inadequacy of Current Teachers in Teaching Cultural Values (f1)" and "Disappearance of Cultural Values Rather Than 
Being Taught (f1)". In addition, in Table 3, sample statements directly quoted from the participants are included to support the relevant themes and codes.

\section{DISCUSSION AND CONCLUSION}

When the findings in Table 2 are investigated, it is observed that the physical education teachers' PES activities in the ceremonies held on national holidays to the students; it has been determined that it provides multidimensional (national, cultural, personal and social) value gain in the form of unity and togetherness, national consciousness, national feeling, social development, self-confidence, respect, taking duty and responsibility and representing the group in the best way. In addition, it has been determined that such activities are significant in transferring cultural values to future generations and they express their opinion that knowing the past will be a guide for the future for students. Apart from this, physical education teachers; they criticized the fact that national holidays are not important and meaningful by parents and school personnel, and they are ceremonies held only for the sake of officiality, and repetitive practices that do not base students on national holidays, distract students from activities, fail to provide unity and not make a balanced distribution of tasks. Regarding these criticisms, it was determined that they suggested that the ceremonies should be held in the form of games and entertainment on a voluntary basis, that the students should work in line with their abilities, that the ceremonies should be held briefly every year without prolonging, and finally that they would gain the love of the country through effective work in the ceremonies.

There are national holidays in Turkey that are celebrated cheerfully with ceremonies and various events at different times of the year. The ceremonies and events held on national holidays are the leading factors that bring the values of a society and ensure the continuity of these values. According to Çelepi (2020) individuals support the continuity of culture by performing or participating in these ceremonies and events. While this process gives the past a chance to live, it simultaneously shapes the future. In this way, the ceremonies and events held on national holidays enable individuals to unite the past and the present, and enable individuals to have an identity and to obtain road maps of the past. The ceremonies and events held thus make both the community and the geography they live in an identity (Çelepi, 2020). Göleç (2019) indicated that ceremonies have a significant value in all societies and these ceremonies have functions such as providing motivation, appreciation and pedagogical development in the lives of individuals, both socially and individually. Ay and Güllü (2020) stated that the ceremonies held on national holidays are important for children such as knowing and discovering themselves, selfconfidence, understanding the importance of unity and team spirit, communication skills, effective speaking, order, discipline, courtesy, obeying the rules of etiquette, exhibiting controlled behavior, obeying the rules shaped they stated that they contributed individually and socially. In Avc1 (2007) stated that one of the most important achievements in national holidays is the days when individuals experience the feeling of unity and togetherness in the best way, he also stated that individuals experience a sense of belonging to their cultural and national values with excitement and enthusiasm during these holidays. In this context, it can be said that it is possible to bring the society together around common values through different ceremonies and activities on national holidays. Şahin and Dönmez (2014) stated that national holidays are important and meaningful for people living in Turkey. New generations have learned and understood the meaning of this struggle, initiated under the leadership of Mustafa Kemal Atatürk, for the establishment of a new state and the liberation of the occupied homeland from the enemy occupation, especially on 19 May 1919, which is considered the actual beginning of the Turkish people's struggle against the enemy in unity and togetherness. They expressed their opinion that it is important to build the future.

Of course, it should not be thought that PES activities held on national holidays only provide physically gain. For example, Esentaş and Işıkgöz (2018) state that the individual or team sports that the students in the school teams do; They have determined that it has positive effects on students in a spiritual sense as well as physical benefits, contributes to the increase of students' quality of life, and is an effective tool for students to be a part of sports culture. Erkal et al. (1998) stated that doing sports improves the ability to understand, bear responsibility and maintain order in cooperation, and that sports make the relations between the individual and society more effective (Erkal et al., 1998). Thus, it can be said that social togetherness and integration can be achieved through PES activities. Particularly on national holidays, with the ceremonies held in the form of sports-specific competitions or shows, individuals can be brought to bear the notion of acting together and keeping group interests superior, which is among the values gained by the phenomenon of sports. In addition, it can be said that the participation of students in these organizations will be important in terms of reconciling and gaining 
national consciousness and national feelings with sports, so it will be possible to raise individuals with multifaceted values thanks to PES. Karacaoğlu (2019) defined national consciousness as the protection of national values by each individual in the society and stated that individuals with national consciousness will undertake the task of transferring the values that are the basis of their belonging to future generations (Karacaoğlu, 2019). In line with this information, combining the holidays, which have a significant position in the improvement of the sense of national unity and togetherness, with the sports activities, it can be thought that it will contribute to the acquisition of positive behaviors and values and to the transfer of the values that are the basis of the existence of the society to the next generations. Arac1 (1999) stated that PES activities; he mentioned that it is a personality training aiming to raise individuals who are healthy, happy, have good morals and balanced personality traits; at the same time, he stated that such activities are an important tool for raising individuals who have national cultural values, who are hardworking, productive, creative, and who assimilate the behaviors required by democratic life. Indeed, it can be observed that PES activities held on national holidays in Turkey strengthen the unity and togetherness of the society and prevent all kinds of positive or negative events from the past from being forgotten. In this context, from the society on national holidays; they can be expected to remember the heroism and achievements of their ancestors and to have an awareness of the values entrusted to them. Therefore, knowing the past will of course be a guide for taking more solid steps for the future. Thus, it can be said that the ceremonies and various activities held on national holidays have a significant position in the sense of keeping a culture alive and seeing the future of a nation by not forgetting its past, as well as keeping the consciousness of unity and togetherness alive.

As a result, when it is considered that belonging to a group is as important a need as basic needs for each individual, it will be easier to meet this need through sports activities to be held on national holidays. The individual will first experience the feeling of belonging to the group through sports activities, and in this way, by taking more duties and responsibilities in order to be effective in the group, in order for the group to be in the best place and to achieve success, will try to represent the group in the best way possible. In this context, the phenomenon of sports obeying the rules, respect, love, peace, do not underestimate the opponent, sportsmanship, responsibility, tolerance, equality, not holding grudges, good morals, shaking hands and congratulations, discipline, self-confidence, helping each other, cooperation, etc. due to the fact that it contains values such as; it can be said that it will be easier to transfer the values that the society needs and need to be preserved to future generations, thanks to the fact that various institutions and organizations give the necessary importance to PES activities. As Pehlivan (2004) states, sports is an effective way of transferring value to individuals and societies, as it is an activity that incorporates honorable concepts such as peace, tolerance, equality, discipline, virtue, selfconfidence, love and respect. In this regard, Martin and Gonzales (2012) pointed out the important role that physical activity and sports play in promoting social and personal values, and indicated that PES activities are a significant element in gaining and transferring value. Doğan et al. (2020) on the other hand, determined that the value perceptions of the students who went to the sports course were higher than the value perceptions of the other students. Regarding this finding, they commented that the students who went to the sports course positively affected the values gained by the PES lesson. Also, they have determined that the students always share the tools and the playgrounds where the PES lessons are held equally, and that they always cooperate in order to reach the goals of the team in the PES lesson. Besides, they found that the students were confident in doing different activities, they always fulfill the different tasks given, they generally took part in organizations connected to PES within the school, and their participation in PES activities increased their desire to succeed. They found that students are always aware of the significance of PES activities, they usually encourage people around them to participate in national holiday events, they usually participate in organized events, they are always happy with the international successes of their country in sports, and they generally recognize their cultural values by participating in activities related to traditional games. Moreover, when the students' views on participation in demonstrations such as sports events and folk dances on national holidays are examined as part of PES lessons; high school students think that it is important to participate in these holidays in terms of national feelings and values, and that students about the sports activities held on the national holiday; they stated that they expressed their opinion that it provides socialization, self-confidence and courage. Sabirova and Zinoviev (2016) stated that children who go to the sport club not only have an environment where they can interact with their peers but also have the chance to socialize with people other than their peers. Contrary to these studies, Şahin and Dönmez (2014) determined that the way of celebrating 19 May the Commemoration of Atatürk, Youth and Sports Day did not 
contribute to the acquisition and development of national feelings (Şahin \& Dönmez, 2014). As a result, it is observed that most of the researches discussed on the subject support the codes related to the "Learning Outcome" theme.

It is of course important to ensure that national holidays are celebrated with a social consciousness, enthusiasm and excitement, as a result, to create a sense of belonging to social and cultural values and to transfer these values to future generations. However, the fact that students and their families, who are a building block in the celebration of national holidays with different activities, witness long-term official speeches on national holidays and have to wait for hours in addition, pressure on families by school managers and teachers to ensure their participation in these ceremonies has recently started to be a matter of discussion. For example, Şahin and Dönmez (2014) stated that students forcibly participate in such activities, that physical education teachers impose sanctions on students' participation in holidays, and that they threaten students with grades or otherwise. In the same study, many PES teachers made their defense on this issue; they stated that a list of how many students they will attend the festival with was sent to them by National Education Directorate, and if they could not attend with enough students, an investigation was launched against them by the inspectors (Şahin \& Dönmez, 2014). These findings are similar to the results of the research. On national holidays; the implementation of official practices that do not take students as a basis, devoid of feelings of fun, and that the relevant personnel and various authorities in schools do not act equally when choosing students for participation in these holidays have created the perception of "ceremonies held for the sake of officialdom" in the minds of students and families about national holidays. These holidays have begun to lose their former importance and meaning gradually, leading to the inability to achieve social unity. From this point of view, considering that national holidays are the pride of a nation, it will be seen that the sports activities held here have an important place in experiencing this feeling. However, at this stage, considering that schools are an institution that produces culture and values and disseminates these facts; it should not be forgotten that they should have an idea that the aim is to instill the consciousness of being a nation, to keep cultural values alive, to make unity and togetherness permanent. Therefore, in order to eliminate the negative attitude created by the society towards national holidays, schools should take the lead in participating in the ceremonies on the basis of voluntariness, the activities to be carried out should not be formally but as games and entertainment, the students should work in line with their abilities, and the ceremonies should be held briefly every year, without extending them. It can be said that with the constructive works to be carried out, the spirit of love for the country and the holiday will be restored. Şahin and Dönmez (2014) determined that in activities related to national holidays, students seek ways to escape from the oppression of the holiday rather than experiencing the joy of the holiday, that holiday activities are organized with an understanding that is in conflict with the values of the society, students are kept in the sun for hours in the stadiums, and many students faint from the heat. Furthermore, they have determined that the holidays are gathered in a common point that they are the holidays that are organized to fulfill an official duty in an attitude that does not take into account the student's health and safety, and that does not value the student as an individual, and that is celebrated with forced activities without being internalized by teachers and students.

In the light of this information, it can be said that the whole community's participation in national holidays and the most important values to be brought to the young generations during these holidays can only be gained through effective and constructive practices by various institutions and organizations. First of all, ensuring that participation in national holidays is done not by imposition but as a work of the heart, and at the same time, the activities are performed in the form of games and entertainment in regard to the development level of the students will develop a positive attitude towards national holidays. As a result, it will be possible for national feelings and national consciousness to settle in the minds of the society. Regarding this issue, Doğan et al. (2020) stated that students attach more importance to visuality and entertainment during these holidays, and that the activities should be organized more devotedly and effectively by the authorities. Ay and Güllü (2020) determined that classroom teachers do not like today's national holiday ceremonies. The reasons for this are; they stated that ceremonies celebrated with excitement and enthusiasm as in the past were not organized, the society in general, and the student mass in particular, the participation of the student mass in the ceremonies, the days when national holidays were started to be perceived as holidays. In addition, classroom teachers; it has been suggested to organize ceremonies celebrated in areas that allow wide participation as before, to carry out studies to understand the importance of national holidays, to revive the old national spirit by raising awareness of families, and to revise and reorganize the regulation applied on national holidays by the Ministry of National Education. Sofi (2008) stated that holidays should be 
celebrated every year in the form of festivals and feasts for all children and youth in the same age group. These findings are similar to the results of the research.

In Table 3 when the findings are examined, it is observed that physical education teachers teach activities that reflect cultural values such as folk dances and traditional games in PES lessons; they stated that teaching these activities is important in terms of keeping Turkish culture alive and transferring it to future generations. Physical education teachers stated that such activities provide team spirit and self-confidence, support social development as they require communication and harmony, directly affect the acquisition of national and spiritual values, keep individuals away from harmful habits, and are important for introducing Turkish culture to individuals from different countries. However, physical education teachers have criticized that existing teachers are insufficient in teaching folk dances and cultural values and that cultural values are gradually disappearing. Regarding these criticisms, physical education teachers; it has been determined that they have suggested that professional educators should provide training on folk dances and that studies should be carried out in order to protect cultural values. In addition, it was determined that a physical education teacher made suggestion for only men to participate in cultural activities in terms of religion.

One of the significant activities of PES lessons is folk dances. According to Uslu (2013), folk dances are an important cultural element that tells the cultural values of the society to which they belong, by making use of movements, rhythms, gestures and mimics, accompanied by music and musical instruments, collectively and sometimes individually (Uslu, 2013). In another definition, Turkish folk dances are called as the whole of aesthetic movements in which individuals who grow up with the culture of the society try to express their feelings and thoughts with the language of body movements in the social life process (Gerek, 2007). Particularly in PES lessons, through folk dances; the cultural values, joys and sorrows of different geographies are tried to be conveyed with clothes that have a meaningful story of the regions and various games performed with these clothes. In this way, it can be said that the transfer of the cultural values that dominate the society to future generations will of course be easier, and a development of society and social can be achieved. In this context, physical education teachers, who are one of the most important basic prnciples of education and training activities, have a great responsibility in transferring cultural values to future generations in PES lessons. So much so that physical education teachers are obliged to implement the plans and programs put into practice by education politicians. Therefore, folk dances activities carried out in PES lessons teach students discipline, self-confidence, awareness of being a group, national and spiritual values, etc. considering that it is a great way to teach many values that can be counted even more, it can be said that students can expect guidance from physical education teachers about the teaching of these values. Even this situation clearly reveals the great responsibility on physical education teachers. In addition, it is a fact that these events will contribute positively to the promotion of the country. Uslu (2013) stated that the students participating in the folk dances activities achieved various gains for learning and sharing, and they increased their selfconfidence. At the same time, he stated that these activities carried out by the students in a collective environment contributed to the socio-cultural improvement of the country and to the promotion of the country's identity. In this way, he stated that the students made a cultural and social service on behalf of their country (Uslu, 2013). Thus, it can be thought that folk dances, which are taught to students in PES lessons at schools and made as practice, will be effective in shaping and exhibiting the behaviors of students in a positive way.

Knowing the truth for individuals prevents them from making mistakes. Sports environments are at the forefront of the environments where individuals learn wrong and right best. It is known that individuals who participate in sports activities, in particular, move away from harmful habits. In this context, it can be thought that it is extremely important for individuals to turn to sports activities. When individuals are faced with a negative situation, they will either escape from this situation or try to cope with this situation. In order for individuals to cope with such situations, they must have a knowledge of what is right and wrong in their minds so that they can behave in accordance with these values. Thus, the fact that the phenomenon of sports brings this awareness and more has been supported by already existing researches. For example, Segrave and Patient (1982), Brown and Siegel (1988) stated that students who participate in sportive activities show less behavioral disorders, increase their academic achievement, have better classroom behaviors, stay away from harmful habits, and develop better social relations (Segrave \& Patient, 1982; Brown \& Siegel, 1988). Therefore, folk dances, which are one of the sports activities and a means of transferring cultural values to future generations; it can be said that it not only helps individuals to organize a visual feast aesthetically but also helps 
individuals to get rid of bad habits, manage their time well and establish more qualified relationships, thus helping them achieve social development. In the light of this information, it should not be forgotten that folk dances provide individuals with versatile value gains (nationalcultural-social). Therefore, it is thought that teaching these activities at all levels of education and training and transferring them to future generations will be important.

Teachers have a great role in transferring the values in question in PES lessons through folk dances. So much so that the teachers' inadequacy in the education of folk dances has also been revealed by the opinions of the participants in the research, and this has led to the gradual disappearance of cultural values. Therefore, training of professional educators on folk dances by carrying out effective studies in order to protect cultural values can enable the realization of the main purposes of folk dances. As Uslu (2013) states, the goal of contributing to the universal culture should be pursued, as well as the preservation and perpetuation of the national culture, by using folk dances, which are our national culture, appropriately, correctly and well. Considering the psycho-social effects that folk dances bring to individuals, especially in the educational environments of children and young people, training services should be provided by master trainers and folk dances studies should be made productive (Uslu, 2013). Yoncalı (2004) states that the importance of physical education in general education is clear, that what makes it important stems from its purpose and scope, and that folk dances are evaluated as a physical education activity within this scope, he stated that it will facilitate the work of physical education teachers with regards to realizing the main objectives of Turkish national education, and that it will also enhance the significance of PES lessons. In addition, he stated that faculties and colleges that train physical education teachers should give importance to this issue and that teachers who teach physical education under the Ministry of National Education should be trained through in-service training programs on the subject (Yoncalık, 2004). Thus, the fact that folk dances, one of the basic elements of Turkish culture, have a meaningful place on education and training processes will support the transfer of cultural values to students first and then to future generations. In addition, folk dances formed by the cultural fabric of a society in this way, it will be performed by other generations by preserving its value. As a result, it is seen that all the explanations and related researches made so far are compatible with the views of physical education teachers, which were analyzed and concluded in this study.

In conclusion, it has been specified that national holidays attended by schools through PES activities and folk dances performances performed during these holidays have an important function in bringing national and cultural values to students and transferring these values to future generations

\section{SUGGESTION}

- Organization of National Holidays by the Ministry of National Education in a format that will raise awareness and pride in Turkish citizens,

- Teaching folk dances as a lesson at all levels of education,

- In future studies, it is recommended to evaluate the opinions of the students about the research subject. 
Yıldız Ö., Deveci A. \& Yıldız Ö. (2021). Opinions of Physical Education Teachers on National and Cultural Values Gained Through Physical Education and Sports Activities. International Journal of Recreation and Sport Science, 5(1); 90-104.

\section{KAYNAKÇA}

Akbayrak, H. (1987). Osmanlı'dan cumhuriyet'e millî bayramlar. Tarih ve Toplum, 8(43), 31-38.

Akturan, U., \& Esen, A. (2008). Fenemonoloji. T. Baş \& U.Aktaran (Ed.), Nitel araştırma yöntemleri, Ankara: Seçkin Yayıncılık.

Altun, A. S. (2003). Eğitim yönetimi ve değerler. Değerler Ĕgitimi Dergisi, 1(1), 7-18.

Aracı H. (2000). Okullarda beden eğitimi. Ankara: Bağırgan Yayınevi.

Arac1, H. (1999). Okullarda beden eğitimi. Ankara: Bağırgan Yayınevi.

Avc1, N. (2007). Resmi bayram ve törenlerin kutlanma şekilleri ile ilgili ögrretmen ve ögrenci görüsleri üzerine bir değerlendirme (Afyonkarahisar örneği) (Yayımlanmamış yüksek lisans tezi). Kocatepe Üniversitesi, Afyonkarahisar.

Ay, T. S., \& Güllü, S. (2020). Sosyal bilgiler dersi bağlamında geçmişten günümüze milli bayram törenleri: Etnografik bir araştırma. Batı Anadolu Eğitim Bilimleri Dergisi, 11(1), 145-168.

Bailey, R. (2006). Physical education and sport in schools: A review of benefits and outcomes. Journal of School Health, 76(8), 397401. doi: 10.1111/j.1746-1561.2006.00132.x

Bailey, R., Armour, K., Kirk, D., Jess, M., Pickup, L., Sandford, R., \& BERA Physical Education and Sport Pedagogy Special Interest Group. (2009). The educational benefits claimed for physical education and school sport: An academic review. Research Papers in Education, 24(1), 127. doi: 10.1080/02671520701809817

Bardi, A. \& Schwartz, H.S. (2003). Values and behavior: Strength and structure of relations. Personality and Social Psychology Bulletin, 29(10), 12071220.

Berg B. L,, \& Lune H. (2019). Sosyal bilimlerde nitel araştırma yöntemleri. (A. Asım, Çev. Ed.), Konya: Eğitim Yayınevi.

Bilgin, N. (2014). Sosyal bilimlerde içerik analizi: Teknikler ve örnek araştırmalar. Ankara: Siyasal Kitabevi.

Brown, J.D., \& Siegel, J.M. (1988). Exercise as a buffer of life stress: A prospective study of adolescent health. Health Psychology, 7(4), 341-353.

Bulger, R. (2015). Establishing a national culture of health and its values. Journal of Thoracic Disease, 7(1), 111-114. doi:10.3978/j.issn.20721439.2015.01.02

Creswell, J. W. (2018). Nitel araştırma yöntemleri: Bes yaklaşıma göre nitel araştırma ve deseni. (M. Bütün, \& S. B. Demir, Çev. Ed.), Ankara: Siyasal Yayıncilık.

Çelepi, M. S. (2020). Toplumsal anımsamanın millî bayramlar ile gerçekleşmesi: 23 Nisan Ulusal Egemenlik ve Çocuk Bayramı örneği. Afyon Kocatepe Üniversitesi Sosyal Bilimler Dergisi, 22(TBMM'nin 100. Y1lı ve Millî İrade Özel Say1s1), 30-43.

Çetin, Ş. (2015). Millî değerlerin öğretimine yönelik tutum ölçeği geçerlik ve güvenirlik çalıșması. Elektronik

Çalışmaları, 10(11), 447-460.

Türkçe

Doğan, İ., Güven, Ö., \& Yıldız, Ö. (2020). Beden eğitimi dersinin ögrenciye kazandirdı $\breve{g} l$ de ğerlerin çeşitli değişkenler açısından incelenmesi. Ankara: Berikan Yayınevi.

Erkan, E. M., Güven Ö., \& Ayan D. (1998). Sosyolojik açıdan spor. İstanbul: Der Yayınları.

Etnier, J. L., Salazar, W., Landers, D. M., Petruzzello, S. J., Han, M., \& Nowell, P. (1997). The influence of physical fitness and exercise upon cognitive functioning: A meta-analysis. Journal of Sport \& Exercise Psychology, 19(3), 249-277.

Fraser-Thomas, J., Côté, J., \& Deakin, J. (2005). Youth sport programs: An avenue to foster positive youth development. Physical Education and Sport Pedagogy, 10(1), 19-40. doi: 10.1080/1740898042000334890

Gerek, Z. (2007). Halk oyunlarl ve spor eğitimi alan üniversite ögrencilerinin fiziksel uygunluklarının eurofit ile karşılaştırılması (Doktora tezi). Gazi Üniversitesi, Ankara.

Glesne, C. (2013). Nitel araştırmaya giriş. (A. Ersoy, \& P. Yalçınoğlu, Çev.). Ankara: Anı Yayıncılık.

Göleç, S. (2019). Osmanl döneminde okula yeni başlayan çocuklar için düzenlenen törenlerin pedagojik açıdan değerlendirilmesi (Yayımlanmamış yüksek lisans tezi). Uludağ Üniversitesi, Bursa.

Gould, D., \& Carson, S. (2008). Life skills development through sport: Current status and future directions. International Review of Sport and Exercise Psychology, 1(1), 58-78. doi: 10.1080/17509840701834573

Gürbüz S., \& Şahin, F. (2018) Sosyal bilimlerde araştırma yöntemleri. Ankara: Seçkin Yayincilik.

Hardman, K., \& Marshall, J. (2005). Physical education in schools in european context: character principles, promises and implementation realities. In K. Green \& K. Hardman, (Eds.), Physical education, essential issues, London: Sage Publications.

İlyas, A. (2018). Yerel basına göre 1935-1950 yılları arasinda Urfa'da mahalli ve milli bayram kutlamaları. Bingöl Üniversitesi Sosyal Bilimler Enstitüsü Dergisi, 8(16), 202-217.

Işıgöz, M. E., Esentaş, M., \& Işıkgöz, M. (2015). Ortaokul öğrencilerinin beden eğitimi ve spor dersine yönelik değer düzeylerinin çeşitli değişkenler açısından incelenmesi: Batman il örneği. International Journal of Social Sciences and Education Research, 4(4), 661-676.

Karacaoğlu, M. Ö. (2019). Millî şuur ve Türk dili: Millî eğitim üzerine yazılar. A. F. Arıc1, \& M. Başaran, (Ed.), İstanbul: Efe Akademi.

Karasar, N. (2008). Bilimsel araştırma yöntemi. Ankara: Nobel Yayınevi.

Kılınç, E. (2018). Nitel araştırmada geçerlilik ve güvenilirlik. Ş. Arslan, (Ed.), İçinde: Sosyal bilimlerde araştırma yöntemleri, Konya: Eğitim Yayınevi. 
Y1ldız Ö., Deveci A. \& Yıldız Ö. (2021). Opinions of Physical Education Teachers on National and Cultural Values Gained Through Physical Education and Sports Activities. International Journal of Recreation and Sport Science, 5(1); 90-104.

Kuş, E. (2003). Nicel-nitel araştırma teknikleri. Ankara: Anı Yayıncilik.

Landers, D. M., \& Petruzzelo, S. J. (1994). The effectiveness of exercise and physical activity in reducing anxiety and reactivity to psychosocial stressors. In H. A. Quinney., L. Gauvin. \& A. E. Wall, (Eds.), Toward active living, Champaign, IL: Human Kinetics.

Martin, J. J. P., \& Gonzalez, J. D. (2012). Teaching values through education at-risk in Spain: an intervention program. International Review on Sport and Violence, 5, 64-83.

Merriam, S. B. (2018). Nitel araştırma: Desen ve uygulama için bir rehber. Ankara: Nobel Akademik Yayıncılık.

Miles, M. B., \& Huberman, A. M. (1994). Qualitative data analysis: An expanded sourcebook. London: Sage Publications.

Morse, J. M. (2010). Procedures and practice of mixed method design: Maintaining control, rigor, and complexity. Sage handbook of mixed methods in social \& behavioral research, London: Sage Publications.

Öçalan, M., \& Erdoğdu, M. (2009). Ortaöğretim kurumlarında beden eğitimi dersinin amaçlarının gerçekleşme düzeyi. Beden Eğitimi ve Spor Bilimleri Dergisi, 3(3), 280-291.

Pehlivan, Z., \& Konukman, F. (2004). Fair-play kavramının geliştirilmesinde okul sporunun yeri ve önemi. Spormetre Beden Eğitimi ve Spor Bilimleri Dergisi, 2(2), 49-53.

Patton, M. Q. (2002). Qualitative evaluation and research methods, Thousand Oaks. CA, Sage Publications Inc.

Prysiazhniuk, S., Tolubko, V., Oleniev D., Parczevskyy, Y., Prontenko, K., Griban, G., \& Zhyrnov O. (2018). The influence of physical activities on biological age parameters of the first-year female students from the special medical department. Journal of Physical Education and Sport, 18(2), 561-564. doi:10.7752/jpes.2018.02081

Pühse, U., \& Gerber, M. (2005). International comparison of physical education: Concepts, problems, prospects. Aachen: Meyer \& Meyer Sport.

Punch, K. F. (2005). Sosyal araştırmalara giriş. (D. Bayrak, \& H. B. Arslan, Z. Akyüz, Çev.), Ankara: Siyasal Kitabevi.

Ritchie, J., Lewis, J., \& Elam, G. (2003). Designing and selecting samples. Qualitative research practice: A guide for social science students and researchers. In Ritchie. J. \& Lewis. J, (Eds), London: Sage Publications.

Roulston, K. (2010). Reflective interviewing: A guide to theory and practice. London: Sage Publications.

Saban, A., \& Ersoy, A. (2017). Eğitimde nitel araştırma desenleri. Ankara: Anı Yayıncılık.
Sabirova, G., \& Zinoviev, A. (2016). Urban local sport clubs, migrant children and youth in Russia. Community Development Journal, 51(4), 482498.

Şahin, M., \& Dönmez, B. (2019). 19 Mayıs Atatürk'ü Anma, Gençlik ve Spor Bayramı hakkında beden eğitimi öğretmenlerin görüşleri. Millı Eğitim Dergisi, 44(202), 193-214.

Şavkili, C., \& Ertem, G. (2019). Kars'ta Cumhuriyet Bayramı kutlamaları (1930-1949). Kafkas Üniversitesi Sosyal Bilimler Enstitüsü, 1(23), 199-226.

Schwartz, H.S., \& Bilsky, W. (1987). Toward a universal psychological structure of human values. Journal Personality and Social Psychology, 53(3), 550-562.

Schwartz, S. H. (1994). Are there universal aspects in the structure and contents of human values. Journal of Social Issues, 50(4), 19-45.

Segrave, J.O., \& Hastad, D.N. (1982). Delinquent behavior and interscholastic athletic participation. Journal of Sport Behavior, 5(2), 96-111.

Shank, G. D. (2006). Qualitative research: A personal skills approach. Upper Saddle River, NJ: Pearson Merrill Prentice Hall.

Sofi, M. (2008). Beden eğitimi ve spor ögretmenlerinin milli bayram (23 Nisan ve 19 Mayls) törenlerine ilişkin problem ve beklentilerin belirlenmesi (Yayımlanmamış yüksek lisans tezi). Sakarya Üniversitesi, Sakarya.

Teddlie, C., \& Tashakkori, A. (2009). Foundations of mixed methods research: Integrating quantitative and qualitative approaches in the social and behavioral sciences. London: Sage Publications.

Topal, Y. (2019). Değerler için ve kök değer. Mavi Atlas, 7(1), 245-254.

Uslu, M. (2013). Halk oyunları çalışmalarının üniversite öğrencilerinin psiko-sosyal gelişimlerine etkisi. Akademik Bakış Uluslararası Hakemli Sosyal Bilimler Dergisi, 39, 1-15.

Uzun, H. (2010). Milletin iradesiyle oluşan bir bayram: Atatürk'ü anma 19 Mayıs gençlik ve spor bayramı ve Atatürk döneminde kutlanışı. Journal of Black Sea Studies, 6(24), 109-125.

Vagle, M. D. (2014). Crafting phenomenological research. California: Left Coast Press.

Yıldırım, A., \& Șimșek, H. (2018). Sosyal bilimlerde nitel araştırma yöntemleri. Ankara: Seçkin Yayıncillk.

Yıldız, Ö., \& Özbay, G. (2013). Beden eğitimi dersi öğrenci değer yönelimi ölçme aracının geliştirilmesi. International Journal of Eurasia Social Sciences, 4(11), 28-42.

Yoncalık, O. (2004). Milli eğitimde bir çocuk yetiştirme alanı olarak halk (dansları) ve beden eğitimi öğretmenliği. Millî Eğitim Dergisi, 164(3). 